\title{
Ewa Kołodziejek, Maria Kabata, Rafał Sidorowicz, E-porady jezykowe, Wydawnictwo Naukowe Uniwersytetu Szczecińskiego, Szczecin 2009, ss. 282
}

Miłośnicy języka polskiego otrzymali nowy poradnik językowy sensu stricto. Jego autorzy, Ewa Kołodziejek, Maria Kabata i Rafał Sidorowicz, są pracownikami Zakładu Etnolingwistyki i Kultury Języka w Instytucie Polonistyki i Kulturoznawstwa Uniwersytetu Szczecińskiego, od wielu lat prowadzą Telefoniczną i Internetową Poradnię Językową. Znane są dokonania Ewy Kołodziejek w popularyzowaniu wiedzy o pięknej i poprawnej polszczyźnie. Jej felietony z zakresu kultury języka, publikowane co tydzień na łamach „Kuriera Szczecińskiego” od 1991 roku, zostały wydane w trzech książkach: Jęzkowa corrida. Jak mówić i pisać poprawnie. Poradnik dla calej rodziny (1995), Językowa corrida 2, czyli walki z bykami ciag dalszy (1999), Licz się ze słowami... Jezzykowa corrida 3 (2003). Tym razem zespół szczecińskich językoznawców (pracujący pod kierunkiem Ewy Kołodziejek) opublikował zbiór porad internetowych udzielonych w latach 2006-2008.

Wykorzystanie internetu, najbardziej ekspansywnego środka komunikacji masowej, do krzewienia wiedzy o języku polskim zasługuje na uznanie. Inicjatywa szczecińskich językoznawców przyczynia się do rozszerzenia sfery poradnictwa językowego jako działalności kulturalnojęzykowej, upowszechniającej wiedzę o języku nowymi sposobami.

Autorzy zauważyli, że od czasu, kiedy telefoniczna poradnia językowa działa w internecie, znacznie poszerzył się krąg ich korespondentów. Dzięki internetowi możliwość zgłoszenia wątpliwości językowych mają nie tylko szczecinianie, ale i mieszkańcy całej Polski, a nawet rodacy przebywający za granicą. Trzeba jednocześnie podkreślić, że poradnictwo językowe na stronach internetu cieszy się coraz większą popularnością, a interesująca nas książka wpisuje się w żywo rozwijający się nurt wydawnictw opartych na działalności 
witryn internetowych poświęconych kulturze języka (np. poradni językowej PWN, poradni językowej Uniwersytetu Śląskiego, forum dyskusyjnego „Gazety Wyborczej”, witryny internetowej Rady Języka Polskiego). Na podstawie zadawanych pytań można zauważyć, że wśród korzystających z usług szczecińskiej poradni są redaktorzy czasopism i wydawnictw, pracownicy agencji reklamowych, urzędnicy, tłumacze, przedsiębiorcy, rodzice pomagający dzieciom w rozwiązywaniu prac domowych, a także miłośnicy języka, żywo reagujący na nowe zjawiska zaobserwowane w polszczyźnie.

Recenzowana książka ma formę bardzo przystępnie napisanego poradnika, składającego się z autentycznych pytań i krótkich, rzeczowych odpowiedzi. Autorzy w swoich odpowiedziach kierują się zasadą, by w sposób możliwie zwięzly i zarazem jasny, nie odbiegając od tematu, bezpośrednio rozwiązywać daną kwestię językowa, przy czym teorię lingwistyczną ograniczają do minimum. Ten sposób doradztwa językowego, z charakterystyczną dla form komunikacji w mediach elektronicznych skrótowością, może zaspokoić doraźne potrzeby przeciętnego użytkownika języka, ale zapewne nie zadowoli osób wyróżniających się rozwiniętą świadomością językową. Tych odbiorców może dziwić fakt, że większość pytań zadawanych przez internautów dotyczy kwestii niezbyt skomplikowanych, których rozstrzygnięcie można znaleźć w dostępnych słownikach języka polskiego albo w słowniku ortograficznym. Ponieważ jednak poradnik nie jest kierowany do specjalistów - językoznawców, ale przede wszystkim do uczniów, studentów, nauczycieli, redaktorów, a także innych osób, które mają liczne wattpliwości językowe, należy wyrazić nadzieję, że pomoże on w codziennej praktyce językowej tym użytkownikom polszczyzny.

Książka szczecińskich polonistów zawiera obraz problemów językowych, z jakimi telefoniczni i internetowi korespondenci zwracali się do poradni, a dotyczących głównie współczesnej polszczyzny, zagadnień ortograficznych i interpunkcyjnych, odmiany nazwisk polskich i obcych, pisowni i odmiany nazw sklepów i firm, tworzenia nazw żeńskich oraz nazw mieszkańców, zapisu skrótowców (np. SPA, 7.PR - Program Ramowy, S.A. czy SA), odmiany i znaczenia wyrazów zapożyczonych (np. absorbent, ban, bimber, faux pas, haker, McDonald's, nordic walking, singiel, symulacja, synergia, rewitalizacja, rewaloryzacja). Odpowiedzi na pytania z poszczególnych działów językoznawstwa zostały pogrupowane w dziewięciu rozdziałach: Jak to powiedzieć?, Gdzie postawić przecinek?, Jak to zapisać?, Jak tworzyć wyrazy i jak je odmieniać?, Jak nadać imię, jak odmienić nazwisko?, Jak odmieniać nazwy miejscowe?, Jak taczq się stowa?, Co znaczq te stowa?, Odrobina uprzejmości.

Niewątpliwą zaletą książki jest różnorodność podejmowanych zagadnień związanych z kulturą i estetyką języka oraz zasadami grzeczności językowej. 
Autorzy obejmują swym zainteresowaniem problemy poprawności nowych elementów językowych, a także zabiegi doskonalące sprawność językową. Poradnik daje podstawy umiejętnego posługiwania się językiem ojczystym, np. w zakresie odmiany nazwisk. Przytacza interesujace opinie w sprawie nadawania imion, często nietypowych, np. Xavier, Colin, Jesse, Maya, Rodryk, Rodryg, Roderyk, Kaj. Książka zawiera też spis słowników, poradników i innych źródeł, z których korzystali autorzy przy rozwiązywaniu problemów językowych, oraz indeks haseł i omówionych form, ułatwiający znalezienie pojedynczych przykładów. Wartość estetyczną książki podnoszą dowcipne rysunki związane z omawianymi zagadnieniami znanego satyryka, Henryka Sawki.

Autorzy w rozstrzygnięciach poprawnościowych stosują się do obowiązujących norm, zawartych w najnowszych ogólnych słownikach języka polskiego, w słowniku poprawnej polszczyzny, ortograficznym oraz w poradnikach innych językoznawców, uznawanych za autorytety w dziedzinie kultury języka. Zdarza się jednak, że pytania dotykają zjawisk nowych, które nie doczekały się jeszcze oceny normatywnej, wówczas autorzy odwołują się do własnych kompetencji i proponują odbiorcy swoje rozwiązanie danej kwestii - zazwyczaj nie budzą one kontrowersji (np. propozycja zapisu tytułu gazety Super-Poznań, pisownia nazwy kraju Czuwaszja, ocena nazwy zespołów AHOOY, $K O M B I I$, ocena nazwy i sposobu wymowy centrum handlowego Galaxy, propozycja nazwania klubu Klub-Cafe, negatywna ocena konstrukcji zabiegi na coś (twarz, ciało)).

Nieliczne rozstrzygnięcia mogą budzić pewne wątpliwości. Nie wydaje mi się przekonujące uzasadnienie pisowni tytułu Opowieści z Narni odwołaniem do zasady ortograficznej: ,jeżeli -ia występuje po $n$, to piszemy $n i$ w wyrazach, których zakończenie wymawiamy jako [-ńa]. Natomiast w tych wyrazach, których zakończenie wymawiamy jako [-nja] piszemy nii” (s. 86). Sadzę, że słowo Narnia jest wymawiane przez współczesnych Polaków na dwa sposoby, nie wiadomo natomiast, który sposób przeważa, a poza tym większość użytkowników języka nie jest świadoma zależności między sposobem wymowy a konsekwencjami w zapisie tego słowa. Świadczy o tym chociażby fakt, że niedawno na ekranach kinowych gościł film Opowieści z Narnii, forma Narnii pojawiała się też na plakatach, w recenzjach, programach, chociaż w wydaniach książkowych powieści stosowana była forma Narni. Nawet gdyby przyjąć, że Narnia jest wymawiana przez [-ńa], to jednak za pisownią z dwoma $i$ przemawia poczucie obcości słowa. Rodzime lub dobrze przyswojone wyrazy wymawiane z końcowym [ńa] tworzą dopełniacz na -ni, wyraźnie obce na -nii, por. dyni, brzoskwini, ale aronii, cukinii, harmonii. Ten argument wspiera również analogia istniejąca między fantastyczną krainą Narnią a nazwami krajów i krain: Hiszpanii, Danii, Kalifornii, Toskanii itp. 
Oceniając hasło akcji społecznej Nie! Ignorantom rowerowym (s. 216) jako niejasne, niefortunne, autor proponuje je zmienić na: Nie ignoruj rowerzystów! Wspomina również, że ignorantem rowerowym może być ten, kto nie zna się na rowerach. Omawiane hasło można zrozumieć jeszcze inaczej, np. Rowerzysto, nie ignoruj przepisów ruchu drogowego! Może o to chodziło pomysłodawcom akcji?

Jedno z pytań skierowanych do poradni brzmi: Jak należy mówić na literę v? W odpowiedzi czytamy: Litera $v$ najczęściej wymawiana jest jak [fat], rzadziej jak [we]. [...] o wymowie decyduje zwyczaj językowy (s. 15). Zapewne przez nieuwagę, może pośpiech, autorka tej odpowiedzi utożsamiła nazwę litery z jej wymowa, a przecież $\mathrm{w}$ języku polskim litera $v$ i litera $w$ są znakiem tej samej głoski, a nazwy tych liter brzmią zupełnie inaczej.

Wyrazem troski autorów o poprawność językową na wszystkich poziomach komunikowania się jest dbałość o to, by nie upowszechniać pojawiających się niekiedy w pytaniach internautów form niepoprawnych. Autorzy konsekwentnie zwracają uwagę na błędy językowe, opatrują je stosownym komentarzem, umieszczając je w cudzysłowie lub poprzedzając wykrzyknikiem - starania te należy przyjąć z uznaniem. Kursywą zapisują omawiane (poprawne) formy wyrazowe.

Nowe możliwości techniczne, jakie stwarza internet, ułatwiają komunikację społeczną, ułatwiają kontakt między językoznawcami a zwykłymi użytkownikami języka. Dzięki temu środkowi komunikacji popularyzowanie wiedzy o języku polskim może stać się skuteczniejsze. Życzę zespołowi szczecińskich językoznawców, by ich książka przyczyniła się do pogłębienia świadomości językowej użytkowników polszczyzny. Sądzę, że modny tytuł ich poradnika, zawierający ekspansywną i pojemną znaczeniową cząstkę $e$-, informującą o nowoczesnym, medialnym sposobie oddziaływania, zachęci szeroki krąg czytelników do zainteresowania się zagadnieniami współczesnej polszczyzny. 